Michał A. Michalski

ORCID: https://orcid.org/0000-0002-9854-0069

Adam Mickiewicz University, Poznań, Poland

\title{
What Happened to Our Will to Serve in the West? Secularization, Individualism, Family and the Decline of the Civilization
}

\begin{abstract}
The West is changing profoundly and so is its cultural and community-building potential. When we observe the transformations of this civilization in such aspects as fertility rates, marriage and divorce statistics, single-parenthood and out-of-wedlock births, birth control and euthanasia, one may look for a common explanation of this phenomena. It seems that people care less for each-other and more about themselves, and spend less time in long-term relationships which demand engagement, devotion and readiness to serve. At the same time, they do not seem to be happier or wealthier.

According to the thesis of my paper, in order to understand and explain the changes listed above it is necessary to analyze them in a wider framework of socio-cultural shifts that took place in recent centuries in the West. This paper concentrates on such phenomena as secularization, rise of individualism and transformations of family life. These elements are going to be tested as key processes which triggered and facilitated profound transformations of culture and social structure which manifest themselves today in such alarming trends as, for example, demographic imbalance due to declining fertility and population ageing, decreasing human capital due to low-quality socialization, population control as well as eugenic practices or feminization of poverty. It seems that the current socio-economic condition of the West calls for critical and thorough analysis of dominating norms, values and beliefs which influence everyday decisions and the actions of millions of people who, in general, do not want to see the decline of their welfare and well-being.
\end{abstract}


The aim of this paper is to engage and combine different findings from such disciplines as economics, psychology, history, sociology and cultural studies in order to present the will to serve which can be described as a foundational dimension and condition of life.

\section{Keywords}

Western Civilization, relationships, will to serve, secularization, individualism, family

\section{I Was Served therefore I Am -Introduction}

In our Western, heavily economized, world one may seem to have forgotten that 'to serve' is not just the phrase linked to 'service society' understood as the next phase of development after the 'industrial society'. What is more, before any 'service' or 'industrial' society may start to function, there is a primary and fundamental sphere of actions and interactions necessary for any nation or state to exist. It is in the family - understood in traditional way as the triad where socio-biological reproduction takes place ${ }^{1}$ - where the human potential becomes actualized in a day-to-day care and nurturing. It is in this special context where the foundations of social order and ability to serve are to be found.

Interesting insights into this influence are offered by Jennifer Roback Morse who writes that "the infant's life in the family lays the foundation for larger social institutions based on trust. Most children learn as infants to trust their parents." It means that, it is mainly through these interactions in the first years of life that human beings gain the necessary skills to participate in society.

The most important conclusion that comes from this knowledge is the fact that it is because spouses serve themselves and, as parents, serve their children

${ }^{1}$ M. Marody, A. Giza-Poleszczuk, Przemiany więzi społecznych. Zarys teorii zmiany społecznej, Warszawa 2004, Wydawnictwo Naukowe Scholar, p. 191; J. Stala, Der gesellschaftlichkulturelle Kontext der aktuellen Gefährdungen für die religiöse Erziehung und Bildung in der Familie, „The Person and the Challenges” Vol. 3 (2013) No 1, pp 251-266; B. Simonič, Empathetic Parenting and Child Development, "The Person and the Challenges" Vol. 5 (2015) No 2, pp. 109-121.

${ }^{2}$ J. Roback-Morse, Love \& Economics: Why the Laissez-Faire Family Doesn't Work, Dallas 2001, Spence Publishing Company, p. 38. 
that the next generation is born and gradually becomes capable of joining society and effectively learns to serve others. At the same time, it is important to notice that even though human beings develop and become more and more independent and able to take care of themselves as they grow older, their existence demands help and service from others. It is well expressed by Roback Morse who writes that, „societies do much better if they face facts rather than ignore them. In particular, political philosophies and their accompanying social philosophies need to address the limits of human power. We are all completely incapacitated in infancy, and even adults at the height of their capacities are far from omnipotent. If philosophies and the societies built around them ignore either of these truths of human helplessness, negative consequences will follow." It becomes evident in this way that helplessness is an essential element of our human condition, no matter what stage of life we are considering. Keeping this in mind becomes more so important, as societies and states try to ensure better conditions of living (or "quality of life") for their citizens.

It seems that there is some kind of neglection of this fact and I believe it is connected with various cases of welfare state regimes. The problem is that, quite often discussions about different solutions for socio-economic development are limited to confronting concepts of socialism and capitalism and do not go beyond this alternative. Consequently, they too often omit the influence of the ideology of welfarism which has become more and more dominating since the 1950's in the West and in other parts of the world, independently of which economic system functions there.

The promise that welfare regimes make is tightly linked to the problem we discuss here because they communicate that the state takes over the responsibility for welfare and well-being of its citizens. In my opinion it is one of these influences that are responsible for the change in procreative attitudes and behaviors which led to the current depopulation of the West. When the state 'promises' to offer welfare and security the society may no longer feel obliged to give birth and prepare the next generation to take over the responsibility for maintaining the standard of living. The problem is that there is nobody but descendants who can keep the socio-economic order working and developing. This becomes somehow blurred in the context of individualized societies enjoying

${ }^{3}$ J. Roback-Morse, Love \& Economics: Why the Laissez-Faire Family Doesn't Work, Dallas 2001, Spence Publishing Company, p. 27; see also p. 28. 
the 'security' of the welfare state. Ulrich Beck and Elisabeth Beck-Gernsheim express it in an interesting way when they write, that "A process of individualization has long been considered a feature of the newly developing bourgeoisie, but in another form it was also distinctive of the 'free wage labourer' of modern capitalism and of the labour market dynamic under the conditions of welfare state mass democracies. Entry into the labour market has repeatedly released people from fixed ties of family, neighbourhood and occupation, as well as from ties to a particular regional culture and landscape. These individualizing thrusts compete with such collective aspects of a labour market destiny as the social risks of wage labour (unemployment, deskilling etc.). But it is only insofar as these risks are reduced - through relative affluence and social protection - that individualization actually leads to a dissolution of life worlds associated with class and status group subcultures."

In this article I am trying to explore and understand the problem of deficits in what is called 'the will to serve'. I believe that it demands a look at such historical processes and phenomena as secularization and individualization; to see how they influenced and transformed Western culture and civilization.

\section{From Family to Socio-Economic Order}

In this section I will show how complete social system originates in the functioning of the primary interactions within the family. It is worth mentioning the contribution of Charles H. Cooley who introduced the idea of a primary group which plays an important role in the socialization of a child. According to Cooley, most fundamental primary groups are the family, the neighbourhood and peer groups. It is also important to keep in mind that these environments start to influence the baby in this order, with family being the first community to shape the newborn human being and help them develop into mature, responsible and virtuous citizens. This fundamental role was clearly stressed by Kenneth E. Boulding, who wrote that "if the market is to be stable and fruitful institution in society it must be hedged around with other institutions of a non-market

U. Beck, E. Beck-Gernsheim, Individualization, Institutionalized Individualism and its Social and Political Consequences, London · Thousand Oaks · New Delhi 2002, SAGE Publications, pp. 30-31. 
character - the home and the school and the church. For here and only here can the motive of responsibility develop."

To understand the structure of this influence, it is useful to engage the contribution of Roback Morse who illustrates how ongoing everyday interactions between parents and a child gradually allow for the development of a mature person. She writes that, "the infant's dependence on adults is more profound than his need to resolve his discomfort, for only adults can teach the child to trust. A child cannot become trusting all by himself, any more than he can hop out of the crib, open the refrigerator, and heat up a bottle of milk for himself. The baby cannot navigate through the cycle of trust without an adult partner."

This fundamental role of family as a primary group has also been explored and further explained by such authors as John Bowlby (in his attachment theory), Peter L. Berger and Thomas Luckmann (in their concept of significant others ${ }^{7}$ ). Recent research by James J. Heckman also shows how the quality of parenting in the first years of the child's life is crucial for further development and achievements in life. $^{8}$

It is also worth mentioning the phenomenon of distribution of work which is embedded in the natural differences between the sexes and individuals, and becomes initially evident in the functioning of a family household. It is here, where all the support and survival become possible through the continued and mutual serving of the needs of family members.

On the basis of the above knowledge it becomes clear that the functioning of macrostructures of society is possible because on the level of microstructures - especially within families - human and social capital are created. In this context this basic primary group, responsible for socio-biological reproduction, is called a mediating structure, because it works as a kind of interface connecting individuals with society. A good example of this role is presented by Roback Morse, who writes that "the banking system of Europe has its

${ }^{5}$ K.E. Boulding, Beyond Economics. Essays on Society, Religion and Ethics, Ann Arbor 1968, The University of Michigan Press, p. 218.

${ }^{6}$ J. Roback-Morse, Love \& Economics: Why the Laissez-Faire Family Doesn't Work, Dallas 2001, Spence Publishing Company, p. 33.

${ }^{7}$ P.L. Berger, T. Luckmann, The Social Construction of Reality A Treatise in the Sociology of Knowledge, London 1991, Penguin Books, pp. 66-68.

${ }^{8}$ J.J. Heckman, Invest in early childhood development: reduce deficits, strengthen the economy. The Heckman Equation, 2012. Available at: http://heckmanequation.org/content/resource/ invest-early-childhood-development-reduce-deficits-strengthen-economy (30.03.2016). 
foundations in the activities of trading families and religious orders during the eleventh, twelfth, and thirteenth centuries. One of the marvellous phenomena of economic development is the extension of those networks of trust, based on personal contact or highly developed reputations, into networks available even to strangers." ${ }^{\prime}$ This relationship is also evident when we take into account that most of the companies have been established as family businesses in their beginning. It is confirmed by the data which shows that, "family firms comprise $80 \%$ to $90 \%$ of all business enterprises in North America; They contribute $64 \%$ of the GDP or nearly $\$ 6$ trillion, and employ $62 \%$ of the U.S. workforce; Australian family businesses make up $67 \%$ of all private sector firms, and employ more than $50 \%$ of the workforce; Family-owned firms represent $70 \%$ of the largest Brazilian business groups. There are roughly 4.1 million family-owned farming enterprises, which employ $77 \%$ of the rural workforce and comprise $84 \%$ of the rural enterprises in the country; At the end of 1999, family firms accounted for almost $80 \%$ of all Finnish companies; The Italian Association of Family Businesses estimates that $93 \%$ of the businesses in Italy are family run; UK Family firms employ 9.5 million people and turnover in excess of $£ 1$ trillion." ${ }^{\prime 10}$

It is also worth reminding here that the family serves as a stabilizing factor which in case of economy and long-term economic development is fundamental. It was Carl Menger who - in the context of familial bonds as main motives for intergenerational transfers between relatives - wrote, that "the passage of goods from the older members of a family into the possession of younger members takes place, not as a result of monetary compensation, but as a result of affection. The family, with its special economic relations, is thus an essential factor in the stability of human economic relations."11

In the specific context of the West it is also necessary to point at the influence of Christianity which profoundly influenced and transformed the cultural profile of this civilization. In general, it recommended a new way of understanding the human individual - treated as a person - and relations and interactions in which he or she was engaged. It resulted in two important phenomena: firstly,

9 J. Roback-Morse, Love \& Economics: Why the Laissez-Faire Family Doesn't Work, Dallas 2001, Spence Publishing Company, pp. 45-46.

${ }^{10}$ Relationships Foundation International, The Penumbra Effect. Family-centred Public Policy, Cambridge 2009, p. 31. Available at: https://relationshipsfoundation.org/publications/ the-penumbra-effect-family-centred-public-policy/ (15.09.2020).

\footnotetext{
${ }^{11}$ C. Menger, Principles of Economics, Auburn 2007, Ludwig von Mises Institute, p. 232.
} 
on a social level it encouraged social love, brotherhood and solidarity which gradually became institutionalized and gave rise to the development of religious orders, hospitals, shelters for homeless, kindergartens, schools and different structures of social security; secondly it radically changed the understanding of marriage and family life in general because it stressed unconditional love, faithfulness, mutual service, obedience and forgiveness. One can conclude this description of Christianity's heritage by stating that it inspired and developed an immeasurable will to serve which gradually transformed the post-barbarian Roman Empire into a civilization which, in recent centuries, has experienced an unprecedented growth of welfare and well-being.

\section{I Will not Serve! - The Role of Secularization and Individualisation in the Transformation of the West}

In the beginning of this section it is necessary to admit that it is not possible to explore and describe in detail the character and outcomes of the processes we are interested in. We are therefore forced to simplify some of the interactions and influences that are subject to analysis.

Starting from the process which we can call the 'Christian revolution', understood as the rise and dissemination of Christianity, we can assume that it has influenced the West in a fundamental way. As already stated above, it ignited the long and difficult process of the transformation of the Roman Empire, founded on slavery, into Western civilization which aspired to become the order based on dignity, freedom, solidarity and mutual service.

In the context of the chosen topic it is reasonable to ask about the condition of this formation today, with special reference to the will to serve. For the purpose of my analysis I will assume that the will to serve can be defined as the readiness to engage in authentic human relationships, and to endure even though the balance may not be positive in terms of advantages. It means that I am going to define the will to serve as the ability to form and sustain asymmetric relationships in which one cannot expect that equality of benefits is guaranteed on both sides. In order to observe this variable, I propose to analyse such data as fertility rates, marriage and divorce ratio, rise in cohabitation and out-ofwedlock births, eugenic abortion and euthanasia. In my opinion they depict the attitude of readiness to engage in relationships where will to serve is one of the essential elements. 
According to the thesis that I propose in this paper, there is a process of progressive weakening in the will to serve in the West that has been occurring/ proceeding since the beginning of modernity. In other words, all the indicators mentioned above point to the problem that can be called the crisis of long-term commitments and engagement, which demands a will to serve as conditio sine qua non.

When it comes to the situation we have these days one can look at the statistics regarding the phenomena listed above and see that: (1) the West is undergoing serious depopulation with fertility rates exceeding the level of 1.3 only in a few countries, whereas the fertility rate should be no lower than 2.1 to guarantee the replacement of society; (2) the number of marriages is decreasing and the number of divorces is growing with $25 \%$ to $50 \%$ of marriages ending in divorce; (3) more and more often people choose cohabitation as a substitute for marriage which is connected with the fact that the number of births out of wedlock is rising (it has been estimated to be about $40 \%$ in recent years); (4) decreasing fertility is connected with the use of contraceptives and abortion which very often is treated in a eugenic way with the refusal to accept any "problematic" offspring; (5) euthanasia is becoming more and more often legalized as a solution for dealing with suffering and the burden of illness.

It is obvious that in every case there is always a complex reality behind these phenomena and it is not easy to offer a simple description or explanation. Yet in humanities and social sciences it is normal when one makes efforts to define and grasp the processes and situations that are not easily explicable.

When it comes to give possible explanations of the crisis of the will to serve that we have in the West, I recommend to go far back in history and draw our attention to the process of secularization which could be dated back to the sixteenth century. It has been one of the most important and fateful shifts in the history of the West. This disruption is appropriately described by Charles Taylor who writes of "a world which seems to proclaim everywhere the absence of God. It is a universe whose outer limits touch nothing but absolute darkness; a universe with its corresponding human world in which we can really experience Godlessness. This is not the way in which our forebears in 1500 could experience spirits and powers, in an encounter with particular things and places. It is more like the way our (élite) forebears in 1700 experienced God's ordering presence, that is, as a diffuse, structuring principle, rather than an object which can be fore grounded. But it is different from this again, because it is the sense of an absence; it is the sense that all order, all meaning comes from us. We encounter 
no echo outside. In the world read this way, as so many of our contemporaries live it, the natural/supernatural distinction is no mere intellectual abstraction. A race of humans has arisen which has managed to experience its world entirely as immanent." ${ }^{\text {"12 }}$

One could ask, what does this secular drive have to do with the topic we are analyzing in this article. Maybe it would not be so important in the case of any other civilization which would choose the path of secularization but in case of the West, shaped and transformed by Christianity which prioritizes love understood as service, it must have had a radical influence. Rejecting the religious perspective can be compared to the manifesto of the fallen angels which declared "we will not serve!". Interestingly - and maybe provocatively for some it is reasonable in this context to look at the reformation which fostered secularization by putting an emphasis on an individualistic interpretation of the Bible and - more or less - an individual coordination of one's religious life ${ }^{13}$. Such an interpretation of reformation can be justified if we look at the general intention and attitude of rejecting obedience towards the pope who, until then, although not always without doubts, had been regarded as the vicar of Christ.

Besides reformation, one has to consider other influences on secularization such as the Renaissance with the developing Cartesian shift towards the 'age of reason', and the Enlightenment with its stress on positivistic approach which deleted metaphysics and theology from the curriculum of sciences. What is significant for these processes is that they announced that from then on, the individual human being and his/her mind were in charge of the world's existence ${ }^{14}$. It is well described by Ulrich Beck and Elisabeth Beck-Gernsheim, who write that individualization is often associated with such positive phenomena as freedom, autonomy, emancipation, and self-liberation of humanity. At the same time this picture is not so optimistic, because the possible result may also be anarchy of "(...) a state unregulated to the point of lawlessness. (...) Any generalization that seeks to understand individualized society only in terms of one extreme or the other - autonomy or anomie - abbreviates and distorts

${ }^{12}$ C. Taylor, A Secular Age, Cambridge, Massachusetts, and London, England 2007, The Belknap Press of Harvard University Press, p. 376.

${ }^{13}$ Cf. C. Taylor, Sources of the Self: The Making of the Modern Identity, Harvard University Press, Cambridge, Massachusetts 1989, p. 215; R. Razum, B.V. Mandarić, Young People, Faith, Spirituality, Ecclesiality, "Bogoslovska smotra” Vol. 84 (2014) No 1, pp. 1083-1108.

${ }^{14}$ Cf. C. Taylor, A Secular Age, Cambridge, Massachusetts, and London, England 2007, The Belknap Press of Harvard University Press, p. 169. 
the questions that confront us here. This society is characterized by hybrid forms, contradictions, ambivalences (dependent on political, economic and family conditions). It is also characterized, as we have said, by the 'do-it-yourself biography' which - depending on the economic situation, educational qualifications, stage of life, family situation, colleagues - can easily turn into a 'breakdown biography'. Failure and inalienable freedom live in close proximity and perhaps intermingle (as in the 'chosen' lifestyle of 'singles'). (...) One can even say that decisions about lifestyles are 'deified'. Questions that went out of use with God are re-emerging at the centre of life. Everyday life is being post-religiously 'theologized"' ${ }^{\prime 15}$

In the light of this fragment, it is justified to say that the West has undergone a profound cultural change, which started with modernization and was followed by postmodernization. It is going to be presented in the next section with some comments on the eugenic approach, as indicated by the title of the chapter.

\section{Postmodernization and Eugenics in the West - the Dilemma Between Civilization and Barbarism}

As we come to the end of our reflection, let us look at the process of postmodernization which somehow explains and continues the work done by secularization and individualisation. These last two phenomena were essential building blocks of modernization which "transformed political and cultural systems from traditional regimes legitimated by religious belief systems to rational-legal states legitimated by their claim to maximize the welfare of their people through scientific expertise. It was a transfer of authority from family and religious institutions to political institutions." ${ }^{\prime 6}$

In terms of the quest for paradise (being fundamental for the Christian civilization) the modern - secularized and individualised - society did not abandon the idea but only transformed it. As a result, all the energy was redirected and engaged in the project of the welfare state which was already mentioned. Its ambitions were similar but limited to this earthly existence. It is accurately described by Chantal Delsol who writes about the welfare state which anonymously

${ }^{15}$ U. Beck, E. Beck-Gernsheim, Individualization, Institutionalized Individualism and its Social and Political Consequences, London · Thousand Oaks · New Delhi 2002, SAGE Publications, p. 7.

${ }^{16}$ R. Inglehart, Modernization and Postmodernization, in: B.E. Brown (ed.), Comparative Politics: Notes and Readings, Belmont, California 2006, Thomson/Wadsworth, p. 67. 
distributes the manna from tax revenues. ${ }^{17}$ The same author shows this difference in such a way: "the Christian creed was, "Love and do as you please"; now we have, "Share your money and do as you please."18

In the course of the twentieth century there has been gradually developing a kind of dissatisfaction with the effectiveness of the welfare state and in this way postmodernization entered the scene. Even though it somehow contested modernity, postmodernization followed the modernity's line of thinking in such fundamental aspects of our analysis as secularization and individualization. This postmodern shift has been summarized by Ronald Inglehart thus. According to him there are five characteristic symptoms of this process: “(1) „A shift from scarcity values to postmodern or security values”; (2 „Diminishing effectiveness and acceptability of bureaucratic authority”; (3) „Rejection of the West as a model and the collapse of the socialist alternative”; (4), Growing emphasis on individual freedom and emotional experience, and rejection of all forms of authority"; (5) "Diminishing prestige of science, technology and rationality."19

As mentioned above, postmodernization continues the secular and individualistic trend, and strengthens autonomy and moral relativism. It becomes especially evident in the case of eugenics, another important feature of our epoque, which rejects the limitations and fragility of human life. In other words, the West does not have a clue on how to approach the finiteness of the human being and his/her existence. At the same time, it does not understand that it is a condition and a necessary element of living together within society - as pointed out in the introduction of the paper. This fundamental issue is explained in an interesting way by Delsol who writes that, "no relationship can be established without acknowledging the finiteness of being. A self-sufficient being would not need anyone and would remain solitary and happy in his own completeness. The structure of the common world is defined by giving, and giving in return, in response to the needs, inadequacies, and dependencies by which finite beings are characterized. Every human relationship begins with a need that one

${ }^{17}$ Cf. C. Delsol, The Unlearned Lessons of the Twentieth Century: An Essay on Late Modernity, 2006, ISI Books, p. 142.

${ }^{18}$ C. Delsol, The Unlearned Lessons of the Twentieth Century: An Essay on Late Modernity, 2006, ISI Books, p. 142.

${ }^{19}$ Cf. R. Inglehart, Modernization and Postmodernization, in: B.E. Brown (ed.), Comparative Politics: Notes and Readings, Belmont, California 2006, Thomson/Wadsworth, pp. 67-70. 
is willing to see filled. The first condition of a "society" is the acknowledgment of our constitutive insufficiency."

It becomes evident in eugenic practices - such as euthanasia or abortion - which lack approval for the unpredictability and imperfections of our existence. In this light, eugenics should be seen rather as the way of escaping relationships and rejecting the need to serve that every human life brings. At the same time, eugenics unveils social darwinism applied to human beings and introduces the survival of the fittest as a new social order paradigm. This once again confirms the progress that secularization made in convincing societies that there is nothing special or sacred about the human being, and that it can be governed by the same rules that were earlier limited to the animal world. One cannot help feeling that the West is making a step backwards from the state of civilization towards some kind of new barbarism...

\section{Conclusion}

In this article I explored the problem of deficits in what is called the will to serve in the Western civilization through the lens of radical changes within family life, and presented a possible explanation which includes such phenomena as secularization and individualisation. I also discussed the topic of eugenics which reveals itself in a number of practices which show that atomized postmodern societies of the twenty-first century would rather avoid long-term commitments and the caring for the other. It all proves that there is something important and worrying happening to our sense of being human and living in a community. We long for security and unconditional acceptance yet, at the same time, the statistics show that our homes become less safe and our relationships more conditional. Probably, these days, many ask, 'how could this have happened?'

It seems that, as a result of secularization, the West has lost its wider perspective resulting in the certainty that this earthly life is not all that we have. If that is the case, then we should agree with Goldman, who says that "without the hope of immortality we cannot bear mortality. Cultures that have lost the

${ }^{20}$ C. Delsol, The Unlearned Lessons of the Twentieth Century: An Essay on Late Modernity, 2006, ISI Books, p. 144. 
hope of immortality also lose the will to live. Culture is the stuff out of which we weave the perception of immortality."21

In the context of our analysis, we can conclude by saying that attitude towards religion and transcendental perspective it brings, seems to be the most profound problem of our civilization. Secularized reduction of life understood as merely individually designed existence questions the sense of community and weakens the will to serve each other. This is one of the costs of rejection of religious perspective which offers wide range of protective effects ${ }^{22}$.

It all seems that the real chance for our societies is to go back to the source which once gave the Western civilization the impulse to live - serve each other and flourish. It harmonizes with the solution offered by Mitch Pearlstein who states that no social policies or funding will suffice to solve the problems of our time. These remedies will not work without spiritual renewals paving the way to fundamental cultural shifts ${ }^{23}$.

\section{Bibliography}

Beck U. and Beck-Gernsheim E., Individualization, Institutionalized Individualism and its Social and Political Consequences, SAGE Publications, London · Thousand Oaks - New Delhi 2002.

Berger P.L., Luckmann T., The Social Construction of Reality: A Treatise in the Sociology of Knowledge, Penguin Books 1991.

Boulding K.E., Beyond Economics. Essays on Society, Religion and Ethics, The University of Michigan Press, Ann Arbor 1968.

Delsol C., The Unlearned Lessons of the Twentieth Century: An Essay on Late Modernity, ISI Books 2006.

Goldman D.P., It's Not the End of the World. It's the End of You. New York: RVP Publishers 2011.

Heckman J.J., Invest in early childhood development: reduce deficits, strengthen the economy. The Heckman Equation, 2012. Available at: http://heckmanequation.org/

${ }^{21}$ D.P. Goldman, It's Not the End of the World. It's the End of You. New York 2011, RVP Publishers, p. 351.

${ }^{22}$ Cf. R.D. Putnam, Bowling Alone: The Collapse and Revival of American Community, Simon \& Schuster, New York 2001, 326.

${ }^{23}$ Cf. M. Pearlstein, From Family Collapse to America's Decline. The Educational, Economic and Social Costs of Family Fragmentation, Rowman \& Littlefield Education, Lanham - New York - Toronto - Plymouth, UK 2011, p. 154. 
content/resource/invest-early-childhood-development-reduce-deficits-strengtheneconomy (30.03.2016).

Inglehart R., Modernization and Postmodernization, in: B.E. Brown (ed.), Comparative Politics: Notes and Readings, Thomson/Wadsworth, Belmont, California 2006.

Marody M., Giza-Poleszczuk A., Przemiany więzi społecznych. Zarys teorii zmiany społecznej, Wydawnictwo Naukowe Scholar, Warszawa 2004.

Menger C., Principles of Economics, Ludwig von Mises Institute, Auburn 2007.

Pearlstein M., From Family Collapse to America's Decline. The Educational, Economic and Social Costs of Family Fragmentation, Rowman \& Littlefield Education, Lanham - New York - Toronto - Plymouth, UK 2011.

Putnam R.D., Bowling Alone: The Collapse and Revival of American Community, Simon \& Schuster, New York 2001.

Razum R., Mandarić B.V., Young People, Faith, Spirituality, Ecclesiality, "Bogoslovska smotra" Vol. 84 (2014) No 1, pp. 1083-1108.

Relationships Foundation International, The Penumbra Effect. Family-centred Public Policy, Cambridge 2009. Available at: https://relationshipsfoundation.org/publications/the-penumbra-effect-family-centred-public-policy/ (15.09.2020).

Roback-Morse J., Love \& Economics: Why the Laissez-Faire Family Doesn't Work, Spence Publishing Company, Dallas 2001.

Simonič B., Empathetic Parenting and Child Development, "The Person and the Challenges" Vol. 5 (2015) No 2, pp. 109-121.

Stala J., Der gesellschaftlich-kulturelle Kontext der aktuellen Gefährdungen für die religiöse Erziehung und Bildung in der Familie, „The Person and the Challenges” Vol. 3 (2013) No 1, pp 251-266.

Taylor C., A Secular Age, The Belknap Press of Harvard University Press, Cambridge, Massachusetts, and London, England 2007.

Taylor C., Sources of the Self: The Making of the Modern Identity, Harvard University Press, Cambridge, Massachusetts 1989. 